Kong. Res. J.1(1) : 69-72, 2014

Kongunadu Arts and Science College, Coimbatore

\title{
HEPATOPROTECTIVE ACTIVITY OF ERIA MYSORENSIS LINDL. (ORCHIDACEAE) PSEUDOBULP AGAINST CARBONTETRACHLORIDE INDUCED TOXICITY
}

\author{
Uma. G., R. Ashok kumar and V. Balasubramaniam* \\ Department of Botany, Kongunadu Arts and Science College, Coimbatore. \\ *E.mail : vbalu61@yahoo.com
}

\begin{abstract}
The ethanolic extract of pseudobulb of Eria mysorensis at the dose of $100 \mathrm{mg} / \mathrm{kg}$ body weight (oral) was studied for the hepatoprotective effect using Carbontetrachloride induced liver damage in wistar albino rats. Ethanolic extract showed significant $(\mathrm{p}<0.05)$ hepatoprotective effect by lowering the serum levels of various biochemical parameters such as serum Glutamic Oxaloacetate Transaminase (SGOT), Serum Glutamic Pyruvates Transaminase (SGPT), Alkaline Phospatase (ALP), Total Bilirubin (TBL), Total Cholesterol (CHL) and by increasing the levels of Total Protein (TPTN) and Albumin (ALB) in the selected model. These biochemical observations were inturn confirmed by histopathological examinations of liver sections and are comparable with the standard hepatoprotective drug Silymarin $(100 \mathrm{mg} / \mathrm{kg}$ body weight $)$ which served as a positive control. The overall experimental results suggests that the biologically active phytoconstituents such as flavonoids, terpenoids, sterols, phenols, saponins and alkaloids present in the ethanolic extract of plant Eria mysorensis, may be responsible for the significant hepatoprotective activity and the results justify the use of Eria mysorensis as a hepatoprotective agent.
\end{abstract}

Keywords: Hepatoprotective activity, Eria mysorensis, pseudobulp.

\section{INTRODUCTION}

India has one of the largest tribal population in the world. The forest plays a vital role in the economy as well as daily needs of the tribals. In times of scarcity when the staple food is in short of supply tribals collect many types of wild roots and tubers to supplement their meagre food available at home(Vidyarthi, 1987). Although orchids are being cultivated and valued mainly for ornamental purposes. Some of them are used from time immemorial in traditional practices to treat various medical conditions. More than 13 species of orchids of traditional importance are reported in Kerala forests(Muktesh Kumar, 1987). Orchids, commonly called for the members of Orchidaceae. Normally grow as epiphytes or often as lithophytes or sometimes as saprophytes. It is one of the most diversified plant families of angiosperms comprising of 18,500 species under 788 genera(Mabberley,1997). Mainly distributed in tropical, subtropical to subtemperate regions of the globe. In India, Orchidaceae is the second most diversified family comprising of 184 genera and 1229 species. Eria is a large genus of orchids with more than 500 species distributed in tropical Asia, Malaysia, Australia, Polynesia and other Pacific islands. It is used for of antidiabetic activity, hepatoprotective activity and aphrodisiac activity. Most of the species have a typical odour of rotting carcasses which attracts the flies to help in their pollination process.

Liver a chief site for intense metabolism and excretion has a surprising role in the maintenance, performance and regulating homeostasis of the body. It is involved with almost all the biochemical pathways to growth, fight against disease, nutrient supply, energy provision and reproduction (Ward and Daly, 1999). The major functions of the liver are carbohydrate, protein and fat metabolism, detoxification secretion of bile and storage of vitamin. Thus, to maintain a healthy liver is a crucial factor for overall health and well being. But it is continuously and variedly exposed to environmental toxins and abused by poor drug habits and alcohol and prescribed and over-the-counter drug which can eventually lead to various liver ailments like hepatitis cirrhosis and alcoholic liver disease (Sharma et al., 1991; Subramaniam and Pushpangadan, 1999). Thus liver diseases are some of the fatal disease in the world today. Therefore, many folk remedies from plant origin are tested for its hepatoprotective liver damage in experimental animal model. Carbon tetrachloride $\left(\mathrm{CCl}_{4}\right)$ induced hepatotoxicity model is widely used for the study of hepatoprotective effects of drugs and plant extracts (Rubinstein, 1962 and Suja et al., 2002). 


\section{MATERIALS AND METHODS}

Plant material E. mysorensis was collected from Velliangiri hills Coimbatore District and is the major hills range of Western Ghats, TamilNadu, India. Collected medicinal plants were identified with the help of field floras (Gamble, 1957; Mathew, 1983; Chandrabose and Nair, 1988). Identification was confirmed at the Botanical survey of India, Southern circle, Coimbatore, TamilNadu.

\subsection{Preparation of the extract}

Plant material pseudobulb was washed with clean tap water to remove dirty and dried under shade to constant weight for 20 days. The pseudobulb were then cut in to pieces and later grinded to powder using an electrical mill. The powdered material were exhaustively extracted with ethanol for $8 \mathrm{hrs}$ using Soxhlet apparatus.The obtained extract was evaporated to dryness at 38 c.

\subsection{Animals}

Wistar Albino rats weighing 180-240g were used in this evaluation. These rats aged between 2.5 and 3 months were procured from animal house of the laboratory of Agricultural University, Trissur, Kerala. They were housed in well ventilated stainless steel cages at room temperature $(24 \pm 2 \quad \dot{c})$ in hygienic condition under natural light and dark schedule and were fed on standard laboratory diet. Food and water were given ad-libitum.

\subsection{Experimental design for hepatoprotective activity}

The rats were divided into 4groups of 5 rats each. The hepatoprotective activity of the plant extracts was tested using $\mathrm{CCl}_{4}$ model. Group I(normal control) received neither the plant extract nor $\mathrm{CCl}_{4}$ for $72 \mathrm{hrs}$ that is they receive food and water only.

\subsection{Carbontetrachloride induced hepatotoxicity}

Rats were divided into four groups of 5 animals each. The rats of control group (I) received three doses of $5 \%$ gumacaciamucilage $(1 \mathrm{ml} / \mathrm{kg}$, per oral.) at 12 hour intervals (0 hour, 12 hour and 24 hour). The ratsof Carbontetrachloride group (II) received three doses of vehicle at 12 hour intervalsand a single dose of Carbontetrachloride $(1.25 \mathrm{ml} / \mathrm{kg}$ i.p.) diluted in liquid paraffin (1:1)30 minutes after the administration of 1st dose of vehicle. The rats of standard group (III) received three doses of Silymarin $(100 \mathrm{mg} / \mathrm{kg})$ at0 hour, 12 hour and 24 hour. Carbontetrachloride was administered $(1.25 \mathrm{ml} / \mathrm{kg}$ i.p.) 30 minutes after the first dose of

silymarin. While the rats of test group (IV) received three doses of test extract at the dose of $200 \mathrm{mg} / \mathrm{kg}$ body weight per oral at 0 hour, 12 hour and 24 hour. Carbontetrachloride was administered $(1.25 \mathrm{ml} / \mathrm{kg}$ i.p.) 30 minutes after the first dose of silymarin test extract (Rao and Mishra, 1997). After 36 hour of administration of Carbontetrachloride, blood was collected and serum was separated and used for determination biochemical parameters.

\subsection{Assessment of Hepatoprotective Activity}

In the present study the hepatoprotective activity was evaluated biochemically and histopathologically. After 72 hours of drug treatment, the animals were dissected under ether anesthesia. Blood from each rat was withdrawn from carotid artery at the neck and collected in previously labeled centrifuging tubes and allowed to clot for 30 min at room temperature. Serum was separated by centrifugation at $3000 \mathrm{rpm}$ for 15 minurtes. The separated serum were used for the estimation of some biochemical parameters like Alanine aminotransferase(ALT/SGPT), Aspartate aminotransferase (AST/SGOT), cholesterol, bilirubin and glucose.

\section{RESULTS AND DISCUSSION}

The effect of ethanol extracts of $E$. mysorensis on initial weight and final weight in normal and liver injured rats were observed. The initial and final body weight, mean weight gain or loss and differences between groups II, III and IV were represented in the table 1 . A significant weight loss was observed in the liver injured control group. The body weights were increased in E. mysorensis extract treated groups $(100,200,500 \mathrm{mg} / \mathrm{kg}$ b.wt.), where as a significant improvement was observed in the group III treated with the standard drug, Silymarin (Fig. 1).

The liver injured rats showed a significant elevation in the total bilirubin, conjucated bilirubin and unconjucated bilirubin when compared to the control group. The administration of ethanol extracts of E. mysorensis treated groups at the concentrations of $100,200,500 \mathrm{mg} / \mathrm{kg}$ b.wt showed significant decreases in the levels of total bilirubin, conjucated bilirubin and unconjucated bilirubin when compared to the liver damacied groups. E. mysorensis extracts treated groups were significantly comparable to the liver injured rats, received silymarin orally at the dose of $100 \mathrm{mg} / \mathrm{kg}$ b.wt. (Table- 2 and Fig. 2). This result is compared to the liver injured rats received silymarin orally at the dose of $100 \mathrm{mg} / \mathrm{kg}$ b.wt. for 14 days. The liver injured group when treated with ethanol extracts of E. mysorensis showed elevated levels of all enzymes in group III and IV as compared to the control group. 
Estimating the activities of serum marker enzymes, like SGPT, SGOT, ALP can make the assessment of liver function when liver cell plasma membrane is damaged, a variety of enzyme normally located in the cytosol are released into the blood stream. Their estimation in the serum is a useful quantitative marker of the extent and type of hepato cellular damage (Mitra et al., 1998). The tendency of these enzymes to return to near normally in extract administered group is a clear manifestation of antihepatotoxic effects of the extract.

Table 1. Effect of E. mysorensis on the body weight of the Rats Before and After Treatment in the normal, Liver damaged and drug treated rats

\begin{tabular}{cccccc}
\hline Treatment & Dose & $\begin{array}{c}\text { Initial Body } \\
\text { Weight(gm) }\end{array}$ & $\begin{array}{c}\text { Final Body } \\
\text { Weight(gm) }\end{array}$ & $\begin{array}{c}\text { Mean Weight } \\
\text { Gain(G)/Loss(L) } \\
\text { (gm) }\end{array}$ & $\begin{array}{c}\text { Percentage } \\
\text { Difference }\end{array}$ \\
\hline Normal control & $0.9 \%$ saline & $173.24 \pm 5.34$ & $179.78 \pm 4.88$ & 6.54 & 3.77 \\
$\begin{array}{c}\text { Liver damged } \\
\text { control }\end{array}$ & $0.9 \%$ saline & $184.45 \pm 6.67$ & $168.58 \pm 5.23$ & 15.87 & 8.60 \\
$\begin{array}{c}\text { Liver damged } \\
\text { Animal + }\end{array}$ & $100(\mathrm{mg} / \mathrm{kg})$ & $182.14 \pm 6.62$ & $191.57 \pm 5.28$ & 9.43 & 5.17 \\
$\begin{array}{c}\text { E. mysorensis } \\
\text { extract }\end{array}$ & $500(\mathrm{mg} / \mathrm{kg})$ & $178.34 \pm 4.85$ & $189.42 \pm 6.58$ & 11.08 & 6.21 \\
$\begin{array}{c}\text { Standard Drug } \\
\text { (Silymarin) }\end{array}$ & $100(\mathrm{mg} / \mathrm{kg})$ & $169.88 \pm 4.74$ & $174.38 \pm 5.63$ & 4.50 & 2.64 \\
\hline
\end{tabular}

Fig. 1: Effect of $E$. mysorensis on the body weight of the Rats Before and After Treatment in the normal, Liver damaged and drug treated rats.

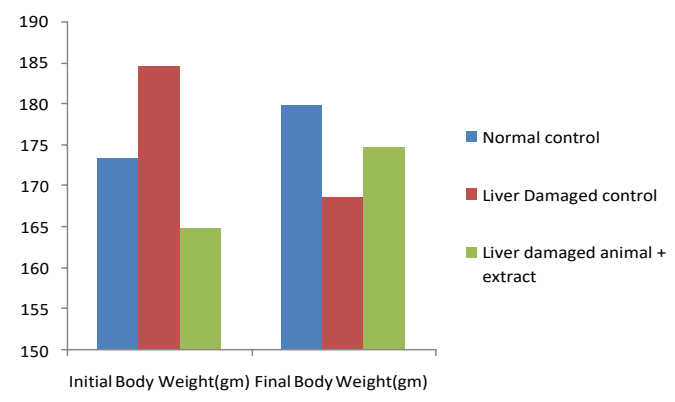

In accordance with these results, it may be confirmed due to the presence of phytoconstituents such as flavonoids, terpenoids, sterols, phenols, saponins and alkaloids which are present in the ethanolic extract could be considered as, responisible for the significant hepatoprotective activity.

Fig. 2: Effect of E. mysorensis extracts on the bilirubin levels (Conjugated and unconjugated) of normal, Liver damaged and drug treated rats.

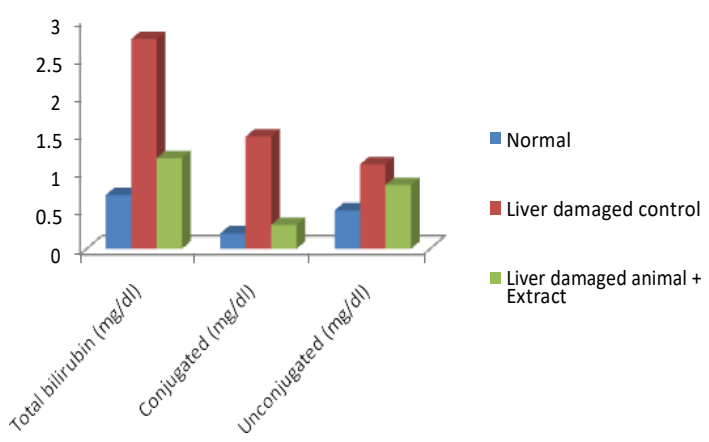

Table 2. Effect of E. mysorensis extracts on the bilirubin levels (Conjugated and unconjugated) of normal, Liver damaged and drug treated rats.

\begin{tabular}{ccccc}
\hline \multirow{2}{*}{ Groups } & \multicolumn{4}{c}{ Parameters } \\
\cline { 2 - 5 } & Dose & Total bilirubin $(\mathrm{mg} / \mathrm{dl})$ & $\begin{array}{c}\text { Conjugated } \\
(\mathrm{mg} / \mathrm{dl})\end{array}$ & Unconjugated $(\mathrm{mg} / \mathrm{dl})$ \\
\hline $\begin{array}{c}\text { Normal } \\
\text { Liver damaged } \\
\text { control }\end{array}$ & $0.9 \%$ saline & $0.70 \pm 0.036$ & $0.20 \pm 0.04$ & $0.50 \pm 0.03$ \\
Liver damaged & $0.9 \%$ saline & $2.73 \pm 0.11$ & $1.46 \pm 0.06$ & $1.10 \pm 0.05$ \\
Animal + & $100(\mathrm{mg} / \mathrm{kg})$ & $1.22 \pm 0.03$ & $0.26 \pm 0.02$ & $0.96 \pm 0.03$ \\
E. mysorensis & $200(\mathrm{mg} / \mathrm{kg})$ & $1.02 \pm 0.04$ & $0.21 \pm 0.04$ & $0.81 \pm 0.04$ \\
extract & $500(\mathrm{mg} / \mathrm{kg})$ & $0.89 \pm 0.03$ & $0.19 \pm 0.02$ & $0.70 \pm 0.06$ \\
& $100(\mathrm{mg} / \mathrm{kg})$ & $0.79 \pm 0.06$ & $0.18 \pm 0.05$ & $0.61 \pm 0.05$ \\
\hline
\end{tabular}




\section{CONCULSION}

In summary, the current study demonstrated that ethanol extract showed a potent protective effect against $\mathrm{CCl}_{4}$-induced liver injury. Ethanol extract pretreatment significantly inhibited the increase of the serum aminotransferase activities, attenuated oxidative stress-induced mitochondrial dysfunction, and decreased the pathological changes. Thus E. mysorensis can be utilized as therapeutics against the liver diseases.

\section{REFERENCES}

Chandrabose, M and N.C. Nair, (1988). Flora of Coimbatore. Bishan Singh and Mahendra Pal singh, Dehra Dun.

Gamble, J.S. and C.E.C. Fischer, (1957). Flora of the Presidency of Madras. 1-3 Calcutta. (Repr.ed).

Mabberley, D.J. (1997). The plant Book. Cambridge.

Mathew, K.M. (1983). Flora of the Tamilnadu Carnatic. 1-3. The Rapinat Herbarium, Tiruchirapalli.

Mitra, S.K., M.V. Venkataranganna, R. Sundaram and S. Gopumadhavan, (1998). Protective effects of HD-03, A herbal formulation, against various hepatotoxic agents in rats.Ethnopharmacol J., 63:181-86.

Muktesh Kumar, Sasidharan N and C. Renuka, (1987). Medicinal orchids of Kerala Forests. Indian J Forestry, 10:216-9.
Rao, K.S. and S.H. Mishra, (1997). Screening of antiinflammatory and hepatoprotective activities of alantolactone isolated from the roots of Inula racemosa. Indian Drugs 34, (10):571-5.

Rubinstein, D. (1962). Epinephrine release andliver glycogen levels after carbon tetrachloride administration. American Journal of Physiology., 203: 1033-1037.

Sharma, A., K.K. Chakraborti and S.S Handa, (1991). Anti-hepatotoxic activity of some Indian herbalformulations as compared to silymarin. Fitoterapia, 62: 229-235.

Subramaniam, A. and P. Pushpangadan, (1999). Development of phytomedicines for liver diseases.Indian J. Pharmacol., 31: 166-175.

Suja, S.R., P.G. Latha, P. Pushpangadan and S. Rajasekharan,, (2002). Aphrodisiac property of Helminthostachys zeylanica in mice. Journal of Tropical Medicinal Plants., 3: 191-195.

Vidyarthi, L.P. (1987). Role of forest in tribal Life. In: Tribals and Forest. (Ed.by.S.P.Sinha) Bihar Tribal welfare Research Institute, Ranchi,pp.323.

Ward, F.M. and M.J. Daly, (1999). Hepatic Disease. In:Clinical Pharmacy and Therapeutics (Walker R.andC.Edwards Eds.). Churchill Livingstone, New York,pp: 195-212. 